\title{
Effects of inorganic and organic nutrients combindly used on yield and quality of groundnut (Arachis hypogaea L.)
}

\author{
Thayamini H. Seran \\ Department of Crop Science, Faculty of Agriculture, Eastern University, Chekalady, Sri Lanka
}

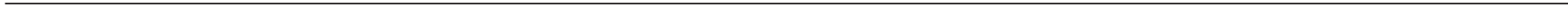

Abstract

This experiment was done to study the effects of combined use of inorganic and organic nutrients on yield and quality of groundnut (Arachis hypogaea L.). Treatment were full doses of NPK fertilizers $\left(\mathrm{N}_{2} \mathrm{P}_{2} \mathrm{O}_{5}: \mathrm{K}_{2} \mathrm{O} @ 16: 45: 45 \mathrm{~kg} / \mathrm{ha}\right)$ alone, Farmyard manure (FYM)@15 ton/ha alone and half doses of NPK fertilizers with FYM@7.5 ton/ha as basal application with or without N@14 kg/ha as top dressing. The results show that highest seed yield $(2558.02$ kg/ha) was obtained in NPK@22.0:22.5:22.5 kg/ha plus FYM@7.5 ton/ha followed by FYM @15 ton/ha with N@14 kg/ha (2521.98 kg/ha). The highest protein (29.9 g) and oil (45.6\%)

Received: 03 July 2017

Revised: 25 February 2018

Accepted: 23 May 2018 contents were recorded in plot treated with FYM alone. It can be concluded that when compared to the standard control, NPK fertilizers@22.0:22.5:22.5 kg/ha with FYM@7.5 ton/ha gave higher seed yield as well as protein $(28.8 \mathrm{~g})$ and oil $(38 \%)$ contents with less environmental impact.
\end{abstract}

DOI: http://dx.doi.org/10.3329/bjsir.v53i4.39193

Keywords: Groundnut; Farm yard manure; Protein and oil contents and seed yield

\section{Introduction}

Groundnut (Arachis hypogaea L.) is a leguminous crop and is mostly used for human consumption in Sri Lanka. It is one of the significant oil crops and requires appropriate amount of plant nutrients at correct time for better yield and quality. Low soil fertility generally causes for reduction in crop productivity. As a result, in conventional agriculture, farmers are used chemical fertilizers for increasing crop productivity. On the other hand, the use of NPK fertilizers alone may lead to deplete the soil micronutrients (Veeramani and Subrahmaniyan, 2011) and also excess application of these fertilizers has resulted environmental problem. In addition, the commercial fertilizers are costly to poor farmers involving in groundnut cultivation. Hence, alternative nutrient management is an essential to overcome the constraints prevailing in Eastern part of Sri Lanka where soil is mostly sandy regosol.

Better organic farming system can give high yield and sustainability in groundnut production (Nagaraj et al., 2001) and this practice has a marked residual effect on the soil nutrient availability (Veeramani and Subrahmaniyan, 2011). Being leguminous crops, groundnut has also ability to fix atmospheric nitrogen which could add some amount of nitrogen to soil. Organic manure can improve soil fertility, increase water-holding capacity, promote beneficial organisms and improve microbial biomass (Hamza and Abd-Elhady, 2010; Esmaeilian et al., 2012). Moreover, organic manure has been used to improve soil physical properties (Busscher et al., 2010) especially aggregate stability (Lado and Ben-Hur, 2004) and penetration resistance in loam soils (Alvarez et al., 2009). Organic manure increases soil fertility and crop production potential possibly by changing physical and chemical properties of soil (Muhammad and Khattak, 2009) and reduce the environmental pollution.

Livestock is a vital part of mixed farming systems (Maass et al., 2012) and in traditional mixed farming, soil fertility of the field is maintained by using available cattle manure (Cox, 2011) which are ecologically safe and friendly. It is a good source of organic matter, an excellent ameliorant to refurbish soil productivity (Miller et al., 2009). Although nutrient contents in cattle manure is relatively lower than chemical fertilizers, 
it is an excellent soil amendment and contains remarkable amounts of primary and secondary nutrients. In many regions, cattle manure applies to improve plant nutrition and yield (Miller et al., 2009; Obour et al., 2010). Application of cow manure biochar to sandy soil is not only beneficial for crop growth, but it also improve soil properties of coarse soil (Uzoma et al., 2011) and reduce groundwater contamination caused by leaching of soil nitrogen. However, the effectiveness of cattle manure depends on manure quality, climate, soil type, crop type, extent of soil degradation and management (Sui et al., 2009). Cow manure is abundantly available in Sri Lanka and other developing countries. Therefore, this study was aimed to evaluate the effects of integrated use of inorganic and organic nutrients on yield and quality of groundnut (Arachis hypogaea L.).

\section{Materials and methods}

Field experiments were conducted under irrigation conditions in 2012-2013 at the Agronomy farm of the Eastern University, Sri Lanka which is located at the latitude of $7^{\circ} 43^{\prime}$ and longitude of $81^{\circ} 42$. During the experimental periods, the average temperatures ranged between $25-35^{\circ} \mathrm{C}$. The minimum and maximum rainfalls during growing season were $7 \mathrm{~mm}$ and 60 $\mathrm{mm}$ respectively. The soil type is sandy regosol.

\section{Experimental design}

The experimental design used was a randomized complete block design with three replications. The treatments were different levels of inorganic and organic nutrients applied to soil as shown in Table I. The recommended full doses of

Table I. Total nutrients applied in this experiment

\begin{tabular}{|c|c|}
\hline Treatment code & e Total nutrients applied to soil \\
\hline T1 (absolute control) & No fertilizer application \\
\hline $\mathrm{T} 2$ & $\mathrm{~N}: \mathrm{P}_{2} \mathrm{O}_{5}: \mathrm{K}_{2} \mathrm{O} @ 16: 45: 45 \mathrm{~kg} / \mathrm{ha}$ \\
\hline T3 (standard control*) & $\mathrm{N}: \mathrm{P}_{2} \mathrm{O}_{5}: \mathrm{K}_{2} \mathrm{O} @ 30: 45: 45 \mathrm{~kg} / \mathrm{ha}$ \\
\hline T4 & Farm yard manure (FYM) @15 ton/ha \\
\hline T5 & FYM@15 ton/ha + N@14kg/ha \\
\hline T6 & $: \mathrm{P}_{2} \mathrm{O}_{5}: \mathrm{K}_{2} \mathrm{O} @ 8.0: 22.5: 22.5 \mathrm{~kg} / \mathrm{ha}+\mathrm{FYM} @ 7.5$ ton/ha \\
\hline $\mathrm{T} 7$ & $: \mathrm{P}_{2} \mathrm{O}_{5}: \mathrm{K}_{2} \mathrm{O} @ 22.0: 22.5: 22.5 \mathrm{~kg} / \mathrm{ha}+\mathrm{FYM} @ 7.5$ ton/ha \\
\hline
\end{tabular}

*Standard control as recommended by Department of Agriculture, Sri Lanka

$\mathrm{N}: \mathrm{P}_{2} \mathrm{O}_{5}: \mathrm{K}_{2} \mathrm{O}$ treatment were $30: 45: 45 \mathrm{~kg} / \mathrm{ha}$ as a standard control to compare yield and quality of groundnut with other treatments. There was also an absolute control treatment where any kind of fertilizers was not applied.

\section{Soil and manure analysis}

Before seeding, soil samples were collected randomly in the experimental area at a depth of $0-15 \mathrm{~cm}$. Likewise air dried Farm yard manure (FYM) was obtained from Dairy farm in the Eastern region of Sri Lanka. The collected samples of soil and FYM were separately mixed thoroughly thereafter physical and chemical analysis was done on dry basis except $\mathrm{pH}$, and electrical conductivity. Available $\mathrm{K}_{2} \mathrm{O}, \mathrm{Ca}, \mathrm{Mg}, \mathrm{Cu} \mathrm{Fe}, \mathrm{Mn}$ and $\mathrm{Zn}$ were determined by using atomic absorption spectrometry. Available Nitrogen and $\mathrm{P}_{2} \mathrm{O}_{5}$ were tested using Kjeldahl and UV visible spectrophotometer respectively. Table II shows the results of the tests obtained.

Table II. Chemical properties of soil and farm yard manure used in this experiment

\begin{tabular}{lll}
\hline Chemical properties & \multicolumn{1}{c}{$\begin{array}{c}\text { Soil at a depth of } \\
0-15 \mathrm{~cm}\end{array}$} & $\begin{array}{l}\text { Farm yard } \\
\text { manure }\end{array}$ \\
\hline Act C.E.C & $2.6 \mathrm{meq} / 100 \mathrm{~g}$ & - \\
$\mathrm{pH}$ & 6.5 & 7.8 \\
Organic carbon & $0.4 \%$ & $22.3 \%$ \\
Electrical conductivity & $32.4 \mu \mathrm{s} \mathrm{cm}^{-1}$ & $3.65 \mu \mathrm{cm}^{-1}$ \\
Nitrogen & $7 \mu \mathrm{g} \mathrm{g}^{-1}$ & $1.12 \%$ \\
Phosphorus as $\mathrm{P}_{2} \mathrm{O}_{5}$ & $35 \mu \mathrm{g} \mathrm{g}-1$ & $0.14 \%$ \\
Potassium as $\mathrm{K}_{2} \mathrm{O}$ & $0.07 \mathrm{meq} / 100 \mathrm{~g}$ & $0.82 \%$ \\
Calcium & $2.0 \mathrm{meq} / 100 \mathrm{~g}$ & $0.44 \%$ \\
Magnesium & $0.30 \mathrm{meq} / 100 \mathrm{~g}$ & $0.30 \%$ \\
Sulphur as sulphate & $8 \mu \mathrm{g} / \mathrm{g}$ & - \\
Boron & $0.09 \mu \mathrm{g} / \mathrm{g}$ & - \\
Copper & $1.1 \mu \mathrm{g} / \mathrm{g}$ & $14 \mathrm{ppm}$ \\
Iron & $33 \mu \mathrm{g} / \mathrm{g}$ & $4896 \mathrm{ppm}$ \\
Manganese & $3.5 \mu \mathrm{g} / \mathrm{g}$ & $524 \mathrm{ppm}$ \\
Zinc & $2.1 \mu \mathrm{g} / \mathrm{g}$ & $76 \mathrm{ppm}$ \\
\hline & &
\end{tabular}

\section{Agronomic practices}

Land was ploughed to a depth of $15-20 \mathrm{~cm}$, and leveled. Subsequently experimental plots were prepared and each plot size was $2.7 \mathrm{~m} \times 1.8 \mathrm{~m}\left(4.86 \mathrm{~m}^{2}\right)$. Seeds of groundnut $\mathrm{cv}$ indi were collected from Seed Production and Processing unit at the Eastern University, Sri Lanka and 
treated with captan at a rate of $3 \mathrm{~g} / \mathrm{kg}$ seeds. The seeds were seeded to maintain one plant per hill at a spacing of $45 \mathrm{~cm} \times 15 \mathrm{~cm}$. The soil was irrigated twice before seeding. Recommended full doses of NPK fertilizers $\left(\mathrm{N}: \mathrm{P}_{2} \mathrm{O}_{5}: \mathrm{K}_{2} \mathrm{O} @ 16: 45: 45 \mathrm{~kg} /\right.$ ha from urea, triple super phosphate and muriate of potash respectively) alone, FYM@15 ton/ha alone and recommended half doses of NPK fertilizers $\left(\mathrm{N}: \mathrm{P}_{2} \mathrm{O}_{5}: \mathrm{K}_{2} \mathrm{O} @\right.$ 8.0:22.5:22.5 kg/ha) with FYM@7.5 ton/ha were basally applied where FYM was done on dry weight basis two weeks before seeding and thoroughly incorporated into the soil but NPK fertilizers were applied at seeding. Further, the respective experimental plots were treated with or without N@14 kg/ha from urea as top dressing which was applied at flowering stage as indicated in Table I. The plots were regularly irrigated to maintain the field capacity and irrigation ceased during last two weeks to mature pods. Weeds were removed manually and no pesticide was applied. and seed weights $(\mathrm{g})$ as well as air dry weights $(\mathrm{g})$ of root and shoot from each tagged plant. Hundred seed weight $(\mathrm{g})$ and plant biomass $(\mathrm{g})$ were recorded. Subsequently shelling \%, pod and seed yields $(\mathrm{kg} / \mathrm{ha})$, biological yield $(\mathrm{kg} / \mathrm{ha})$ and harvest index were calculated. Protein and oil contents in groundnut seeds stored for one year were determined according to AOAC (1990).

\section{Statistical analysis}

Data collected were subjected to analysis of variance (ANOVA) using Statistical Analysis System (SAS) software (SAS version 9.1, Institute INC., Cary, USA). Treatment means were compared according to Tukey's honestly significant difference test at $\alpha=0.05$ probability level.

\section{Results and discussion}

Pod and nodule numbers

The numbers of pods and nodules per plant were significantly $(\mathrm{P}<0.05) \quad$ influenced by the fertilizer

Table III. Effect of fertilizer treatments on pod and nodule numbers as well as weights of pods and seeds per groundnut plant

\begin{tabular}{ccccc}
\hline Treatments & Number of pods & $\begin{array}{c}\text { Number of } \\
\text { nodules }\end{array}$ & $\begin{array}{c}\text { Air dry pod } \\
\text { weight }(\mathrm{g})\end{array}$ & $\begin{array}{c}\text { Air dry seed } \\
\text { weight }(\mathrm{g})\end{array}$ \\
\hline T1 & $11.00 \pm 0.58 \mathrm{~d}$ & $32.33 \pm 1.45 \mathrm{~d}$ & $11.43 \pm 0.72 \mathrm{c}$ & $05.86 \pm 0.36 \mathrm{c}$ \\
T2 & $18.00 \pm 0.58 \mathrm{c}$ & $46.67 \pm 1.67 \mathrm{c}$ & $19.93 \pm 1.23 \mathrm{~b}$ & $12.68 \pm 1.02 \mathrm{~b}$ \\
T3 & $22.67 \pm 0.67 \mathrm{ab}$ & $50.33 \pm 1.60 \mathrm{c}$ & $24.70 \pm 1.70 \mathrm{ab}$ & $16.11 \pm 0.80 \mathrm{ab}$ \\
T4 & $21.33 \pm 0.88 \mathrm{bc}$ & $52.33 \pm 1.45 \mathrm{abc}$ & $23.84 \pm 1.53 \mathrm{ab}$ & $15.80 \pm 1.07 \mathrm{ab}$ \\
T5 & $23.33 \pm 0.88 \mathrm{a}$ & $59.00 \pm 0.89 \mathrm{a}$ & $25.40 \pm 1.45 \mathrm{a}$ & $17.02 \pm 1.05 \mathrm{a}$ \\
T6 & $20.66 \pm 0.88 \mathrm{bc}$ & $57.67 \pm 0.88 \mathrm{ab}$ & $22.31 \pm 1.52 \mathrm{ab}$ & $14.31 \pm 0.86 \mathrm{~b}$ \\
T7 & $23.67 \pm 0.33 \mathrm{a}$ & $54.00 \pm 2.08 \mathrm{bc}$ & $25.96 \pm 1.11 \mathrm{a}$ & $17.27 \pm 0.89 \mathrm{a}$ \\
F test & $* *$ & $* *$ & $* *$ & $* *$ \\
CV\% & 6.52 & 5.62 & 11.44 & 11.43 \\
\hline
\end{tabular}

** - $\mathrm{P}<0.01$. Values are means \pm standard error of three replications. Means followed by the same letter are not significantly different from each other according to Tukey's honestly significant difference test at $5 \%$ significant level

\section{Agronomic parameters}

Mature groundnut plants were uprooted in 110 days after seeding and dried under sunlight for three days. Data were collected on agronomic parameters such as number of pods, number of nodules, leaf area $\left(\mathrm{cm}^{2}\right)$, air dry pod treatments than those in an absolute control (T1). There was markedly higher number of pods in $14 \mathrm{~kg} / \mathrm{ha}$ nitrogen treated plants as top dressing (T3-NPK@30:45:45 kg/ha; T5-FYM@15 ton/ha+N@14 kg/ha and T7- NPK@ 22.0:22.5:22.5 kg/ha + FYM @7.5 ton/ha) over to without top dressed plants (T2-NPK @ 16:45:45 kg/ha; 
T4-FYM@15 ton/ha and T6-NPK@8.0:22.5:22.5 kg/ha +FYM@7.5 ton/ha) however, this application did not show remarkable improvement in nodulation compared to the without top dressed plants (Table III). Significantly highest number of pods (23.67) was recorded in $\mathrm{T} 7$ followed by T5 (23.33) and T3 (22.67) and those were statically similar with each other. Moreover, pod numbers in T4 and T6 were not significant with T3. Further, it was noted that FYM alone or in combination with reduced level of recommended NPK fertilizers resulted in higher number of nodules compared to the recommended NPK fertilizers (T3).

\section{Pod and seed weights}

The fertilizer treatments had considerable $(\mathrm{P}<0.05)$ effect on mean weights of pods and seeds per plant than an absolute control which gave lower values in both parameters (Table III). The highest weights of pods $(25.96 \mathrm{~g})$ and seeds (17.27 g) per plant were obtained in T7 followed by T5 having values of $25.40 \mathrm{~g}$ and $17.02 \mathrm{~g}$ respectively whereas $\mathrm{T} 3 \mathrm{had} 24.7 \mathrm{~g}$ of pod weight and $16.11 \mathrm{~g}$ of seed weight. Addition of FYM exhibited better result (T7 and T5) which were statically on par with T3. The increasing nitrogen application from $8 \mathrm{~kg} / \mathrm{ha}$ (T6) to $22 \mathrm{~kg} / \mathrm{ha}$ (T7) remarkably increased seed weight by $20.7 \%$ than that in T6 but seed weight was significantly similar in T4 (15.8 g) and T5 (17.02) though additional $14 \mathrm{~kg} / \mathrm{ha}$ nitrogen were applied in T5. Seed weight was increased by $7.7 \%(17.02 \mathrm{~g})$ in $\mathrm{T} 5$ and $9.3 \%(17.27 \mathrm{~g})$ in $\mathrm{T} 7$ over to the application of FYM@15 ton/ha alone (T4).

\section{0 seed weight and shelling \%}

Significant effect on hundred seed weight and shelling $\%$ were noted by the fertilizer applications (Table IV). Among the treatments, FYM@15 ton/ha with 14 N kg/ha (T5) had higher weight (54.77 g) which was on par with the other treatments except $\mathrm{T} 1$. In all fertilized plants, 100 seed weight ranged from $49.92 \mathrm{~g}$ (T2) to $54.77 \mathrm{~g}$ where T3, T4 and T7 had about $53 \mathrm{~g}$ meanwhile shelling $\%$ in the fertilized plants was between $63.47 \%$ (T2) and $66.99 \%$ (T5). Significantly lowest value of $51.48 \%$ was recorded in $\mathrm{T} 1$ among the treatments.

\section{Plant biomass}

There were remarkable differences $(\mathrm{P}<0.05)$ in leaf area, root, and shoot weights and also plant biomass between the treatments (Table IV and V). The fertilized treatments had significantly higher values in these parameters except root weight than those in the absolute control (T1). Highest leaf area $\left(853.36 \mathrm{~cm}^{2}\right)$ and shoot weight (17.88 g) per plant were recorded in $\mathrm{T} 7$ and $\mathrm{T} 5$ respectively however there was no significant variation in shoot weight between T7 and T5. Shoot weight and plant biomass ranged from $12.34 \mathrm{~g}$ and $34.09 \mathrm{~g}$ (T2) to $17.88 \mathrm{~g}$ and 48.17 (T5) respectively in the treated plants.

Table IV. Effect of fertilizer treatments on 100 seed weight, shelling \%, leaf area and root and shoot of weights of groundnut plant

\begin{tabular}{lccccc}
\hline Treatments & $\begin{array}{c}\text { 100 Seed } \\
\text { weight }(\mathrm{g})\end{array}$ & $\begin{array}{c}\text { Shelling } \\
\%\end{array}$ & $\begin{array}{c}\text { Leaf area } \\
\left(\mathrm{cm}^{2}\right)\end{array}$ & $\begin{array}{c}\text { Root dry } \\
\text { weight }(\mathrm{g})\end{array}$ & $\begin{array}{c}\text { Shoot dry } \\
\text { weight }(\mathrm{g})\end{array}$ \\
\hline T1 & $43.80 \pm 2.39 \mathrm{~b}$ & $51.48 \pm 3.20 \mathrm{c}$ & $389.04 \pm 07.40 \mathrm{e}$ & $1.79 \pm 0.06 \mathrm{~b}$ & $08.44 \pm 0.44 \mathrm{c}$ \\
T2 & $49.92 \pm 3.09 \mathrm{ab}$ & $63.47 \pm 1.24 \mathrm{~b}$ & $679.27 \pm 17.79 \mathrm{~cd}$ & $1.82 \pm 0.03 \mathrm{ab}$ & $12.34 \pm 0.89 \mathrm{~b}$ \\
T3 & $53.91 \pm 2.46 \mathrm{a}$ & $65.40 \pm 1.35 \mathrm{ab}$ & $786.45 \pm 18.60 \mathrm{ab}$ & $1.90 \pm 0.06 \mathrm{ab}$ & $14.90 \pm 1.22 \mathrm{ab}$ \\
T4 & $53.45 \pm 2.48 \mathrm{a}$ & $66.24 \pm 1.03 \mathrm{ab}$ & $627.27 \pm 21.43 \mathrm{~d}$ & $1.94 \pm 0.02 \mathrm{ab}$ & $14.81 \pm 0.53 \mathrm{ab}$ \\
T5 & $54.77 \pm 2.10 \mathrm{a}$ & $66.99 \pm 0.61 \mathrm{a}$ & $735.45 \pm 10.41 \mathrm{bc}$ & $2.13 \pm 0.09 \mathrm{a}$ & $17.88 \pm 0.95 \mathrm{a}$ \\
T6 & $51.11 \pm 1.96 \mathrm{ab}$ & $64.24 \pm 0.65 \mathrm{ab}$ & $762.50 \pm 15.40 \mathrm{bc}$ & $1.98 \pm 0.02 \mathrm{ab}$ & $12.99 \pm 1.07 \mathrm{~b}$ \\
T7 & $53.52 \pm 2.57 \mathrm{a}$ & $66.48 \pm 0.89 \mathrm{ab}$ & $853.36 \pm 30.34 \mathrm{a}$ & $2.01 \pm 0.12 \mathrm{ab}$ & $16.32 \pm 0.88 \mathrm{a}$ \\
F test & $*$ & $* *$ & $* *$ & $*$ & $* *$ \\
CV\% & 7.88 & 4.14 & 4.68 & 5.90 & 12.18 \\
\hline
\end{tabular}

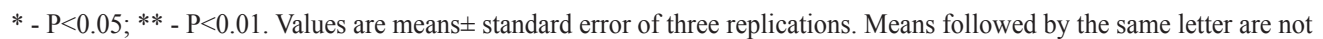
significantly different from each other according to Tukey's honestly significant difference test at $5 \%$ significant level 
Application of nitrogen fertilizer as top dressing significantly increased plant biomass in $\mathrm{T} 7$ than that in T6 (without top dressing) and this cultural practice enhanced plant biomass in other treatments too.

\section{Pod and seed yields}

The pod and seed yields were signifi cantly $(\mathrm{P}<0.01)$ affected by the application of fertilizers. The reduced dose of NPK fertilizers with FYM @ 7.5 ton/ha (T7) was statically on par in pod yield with the other treatments except T1 and T2 (Table V). The average pod yield ranged from $1693.63 \mathrm{~kg} / \mathrm{ha}$ (absolute control T1) to 3845.43 $\mathrm{kg} / \mathrm{ha}$ (T7). When nitrogen fertilizer was applied as top dressing it improved the pod and seed yields of groundnut. There was no remarkable difference in average seed yield between FYM@15 ton/ha alone (T4) andFYM@15 ton/ha with N@14 kg/ha(T5) but it was noted that the addition of N@14 kg/ha as topdressing in T3 (NPK fertilizers alone) and T7 (NPK fertilizers with FYM) had significant $(\mathrm{P}<0.05)$ effect on economic yield over the T2 and T6 respectively. Maximum seed yield was obtained in T7 $(2558.02 \mathrm{~kg} / \mathrm{ha})$ followed by T5 $(2521.98$ $\mathrm{kg} / \mathrm{ha}$ ) and T3 (2387.16 kg/ha). Moreover, seed yield in the standard control (T3) was relatively similar to that $(2340.25 \mathrm{~kg} / \mathrm{ha})$ in T4 (FYM alone).

\section{Harvest index}

There was significant $(\mathrm{P}<0.05)$ difference in harvest index between the fertilizer treatment and absolute control however, application of NPK fertilizers or FYM alone or even in combination with FYM had no effect (Table V). Highest value of harvest index $(38.96 \%)$ was recorded in NPK fertilizers with FYM treatment (T7) followed by the standard control (T3), and FYM alone (T4) whereas absolute control (T1) had lowest value of $27.01 \%$ in the present study. Nitrogen application as top dressing increased harvest index in $\mathrm{T} 3$ and $\mathrm{T} 7$, as compared with $\mathrm{T} 2$ and $\mathrm{T} 6$ respectively.

\section{Protein and oil contents}

The application of FYM alone significantly $(\mathrm{P}<0.05)$ increased the protein and oil contents in seeds over the standard control or combined use of FYM and NPK fertilizers (Table VI). The highest protein (29.9 g) and oil $(45.6 \%)$ contents were recorded in plot treated with FYM alone. Further, it was noted that both contents were considerably reduced in treatment T3 and T5 (plants treated with nitrogen as topdressing) than those in T2 and T4 (plants untreated with nitrogen as top dressing) because T3 and T5 gave high seed yield than that in T2 and T4. When compared T6 (NPK@8.0:22.5:22.5 kg/ha +FYM@7.5 ton/ha) and T7 (NPK@22.0:22.5:22.5 kg/ha+FYM@7.5 ton/ha), protein content in seed was increased by increasing nitrogen level in $\mathrm{T} 7$ whereas oil content was decreased.

Macro and micro nutrients are necessary to enhance the seed production of groundnut. On contrary, farmers in

Table V. Effect of fertilizer treatments on plant biomass, pod and seed yields and also harvest index in groundnut

\begin{tabular}{lcccc}
\hline Treatments & $\begin{array}{c}\text { Plant biomass } \\
(\mathrm{g})\end{array}$ & $\begin{array}{c}\text { Pod yield } \\
\left(\mathrm{kg} \mathrm{ha}^{-1}\right)\end{array}$ & $\begin{array}{c}\text { Seed yield } \\
\left(\mathrm{kg} \mathrm{ha}^{-1}\right)\end{array}$ & $\begin{array}{c}\text { Harvest Index } \\
(\%)\end{array}$ \\
\hline T1 & $21.67 \pm 1.13 \mathrm{c}$ & $1693.63 \pm 107.38 \mathrm{c}$ & $868.15 \pm 53.03 \mathrm{~d}$ & $27.01 \pm 1.42 \mathrm{~b}$ \\
T2 & $34.09 \pm 1.06 \mathrm{~b}$ & $2952.59 \pm 181.61 \mathrm{~b}$ & $1878.02 \pm 120.39 \mathrm{c}$ & $37.19 \pm 2.73 \mathrm{a}$ \\
T3 & $41.50 \pm 2.63 \mathrm{ab}$ & $3659.75 \pm 252.56 \mathrm{ab}$ & $2387.16 \pm 139.03 \mathrm{ab}$ & $38.90 \pm 0.77 \mathrm{a}$ \\
T4 & $40.59 \pm 2.04 \mathrm{ab}$ & $3532.35 \pm 226.47 \mathrm{ab}$ & $2340.25 \pm 148.04 \mathrm{ab}$ & $38.85 \pm 0.73 \mathrm{a}$ \\
T5 & $48.17 \pm 1.19 \mathrm{a}$ & $3762.96 \pm 214.86 \mathrm{a}$ & $2521.98 \pm 146.24 \mathrm{a}$ & $37.47 \pm 1.66 \mathrm{a}$ \\
T6 & $37.28 \pm 0.83 \mathrm{~b}$ & $3304.69 \pm 225.46 \mathrm{ab}$ & $2120.49 \pm 118.05 \mathrm{bc}$ & $38.38 \pm 2.04 \mathrm{a}$ \\
T7 & $44.28 \pm 1.76 \mathrm{a}$ & $3845.43 \pm 165.17 \mathrm{a}$ & $2558.02 \pm 132.53 \mathrm{a}$ & $38.96 \pm 0.76 \mathrm{a}$ \\
F test & $* *$ & $* *$ & $* *$ & $*$ \\
CV\% & 7.07 & 11.43 & 11.43 & 8.12 \\
\hline
\end{tabular}

* $-\mathrm{P}<0.05 ; * *-\mathrm{P}<0.01$. Values are means \pm standard error of three replications. Means followed by the same letter are not significantly different from each other according to Tukey's honestly significant difference test at $5 \%$ significant level 
most part of the semi-arid region use inadequate and imbalance nutrients which is one of the causes for low yield in groundnut (Veeramani and Subrahmaniyan, 2011). Addition of organic manures improved total $\mathrm{N}$, available $P$ and exchangeable $K$ superior than NPK fertilizer (Adeniyan et al., 2011). In the present study, considerably highest number of pods (23.67) as well as pod weight $(25.96 \mathrm{~g})$ per plant were recorded in T7 (NPK @ 22.0:22.5:22.5 kg/ha+FYM@7.5 ton/ha) followed by T5 (FYM@15 ton/ha+N@14kg/ha) over those in the standard control (T3-NPK@30:45:45 kg/ha) while remarkably lowest value was recorded in untreated plots (Table III). FYM consists of macro and micro nutrients as a result $\mathrm{T} 7$ and $\mathrm{T} 5$ exhibited better results which were statically on par with T3. Farm yard manure releases nutrients slowly and it is available to the plants even later stage of plant growth. The nutrient removal by plants depends on soil fertility. The plants tend to absorb more nutrients from the soil and this increases the pod weight of groundnut. This could be attributed to nutrient content in soil treated with FYM.

Nitrogen fertilizer (14 kg nitrogen per ha) applied as top dressing significantly increased plant biomass in T7 (nitrogen treated plants as topdressing) than that in T6 (nitrogen untreated plants). This is in accordance with Aruyi et al. (2000) who stated that nitrogen fertilizers applied at high level showed vegetative growth. In the present study, highest seed yield was achieved in $\mathrm{T} 7$ $(2558.02 \mathrm{~kg} / \mathrm{ha})$ followed by T5 $(2521.98 \mathrm{~kg} / \mathrm{ha})$ and T3 (2387.16 kg/ha). Further, the standard control (T2) was comparatively similar to that $(2340.25 \mathrm{~kg} / \mathrm{ha})$ in T4 (FYM alone). Organic materials enhanced soil properties to boost plant growth (Tirol-Padre et al., 2007; Shakil et al., 2012) thus cowdung increases the effectiveness of mineral fertilizers to improve plant yield (Miller et al., 2009; Obour et al., 2010). Hameed et al. (1993) reported that increase in fertilizer level upto 50:75:30 NPK kg/ha improved groundnut seed yield. Cattle manure@15 ton/ha with EM can use for better economic yield of groundnut (Seran and Suthamathy, 2013).

The moisture content of groundnut before storage was between $8-9 \%$. The seeds obtained in this experiment were tested for aflatoxin. The result showed that there was no aflatoxin contamination. It might be due to the availability of sulphur content in soil. Addition of FYM alone significantly increased the protein and oil contents in seeds over the standard control or combined use of FYM and NPK fertilizers (Table VI). Ipinmoroti et al.

Table VI. Effect of fertilizer treatments on seed protein and oil contents of groundnut

\begin{tabular}{|c|c|c|c|c|}
\hline \multirow{2}{*}{$\begin{array}{l}\text { Treatment } \\
\text { code }\end{array}$} & \multicolumn{2}{|l|}{ Plant nutrients applied } & \multirow{2}{*}{$\begin{array}{l}\text { Protein } \\
(\mathrm{g})\end{array}$} & \multirow{2}{*}{$\begin{array}{l}\text { Oil } \\
(\%)\end{array}$} \\
\hline & Basal dressing & Top dressing & & \\
\hline $\mathrm{T} 1$ & None & None & $26.6 \mathrm{e}$ & $39.3 \mathrm{~d}$ \\
\hline $\mathrm{T} 2$ & $\mathrm{~N}: \mathrm{P}_{2} \mathrm{O}_{5}: \mathrm{K}_{2} \mathrm{O} @ 16: 45: 45 \mathrm{~kg} / \mathrm{ha}$ & None & $28.6 b$ & $40.6 \mathrm{c}$ \\
\hline $\mathrm{T} 3$ & $\mathrm{~N}: \mathrm{P}_{2} \mathrm{O}_{5}: \mathrm{K}_{2} \mathrm{O} @ 16: 45: 45 \mathrm{~kg} / \mathrm{ha}$ & $\mathrm{N} @ 14 \mathrm{~kg} / \mathrm{ha}$ & $26.1 \mathrm{f}$ & $33.4 \mathrm{f}$ \\
\hline $\mathrm{T} 4$ & *FYM@15 ton/ha & None & $29.9 \mathrm{a}$ & $45.6 \mathrm{a}$ \\
\hline T5 & *FYM@15 ton/ha & N@14kg/ha & $27.1 \mathrm{~d}$ & $40.5 \mathrm{c}$ \\
\hline T6 & $\begin{array}{l}\mathrm{N}: \mathrm{P}_{2} \mathrm{O}_{5}: \mathrm{K}_{2} \mathrm{O} @ 8.0: 22.5: 22.5 \mathrm{~kg} / \mathrm{ha} \\
+\mathrm{FYM} @ 7.5 \text { ton } / \mathrm{ha}\end{array}$ & None & $27.6 \mathrm{c}$ & $42.2 b$ \\
\hline \multirow[t]{2}{*}{$\mathrm{T} 7$} & $\begin{array}{l}\mathrm{N}: \mathrm{P}_{2} \mathrm{O}_{5}: \mathrm{K}_{2} \mathrm{O} @ 8.0: 22.5: 22.5 \mathrm{~kg} / \mathrm{ha} \\
+\mathrm{FYM} @ 7.5 \text { ton } / \mathrm{ha}\end{array}$ & $\mathrm{N} @ 14 \mathrm{~kg} / \mathrm{ha}$ & $28.8 b$ & $38.4 \mathrm{e}$ \\
\hline & F test & & $* *$ & $* *$ \\
\hline
\end{tabular}

*FYM-Farm yard manure

Values are means \pm standard error of three replications. Means followed by the same letter are not significantly different from each other according to Tukey's honestly significant difference test at 5\% significant level 
(2008) reported that soil fertility in N, P, K, CA and Mg was improved by the application of organic manure than NPK fertilizers. When compared to treatment T6, protein content in groundnut seed was increased by increasing nitrogen level in T7 whereas oil content was decreased (Table VI). Kandil et al. (2007) stated that the increasing nitrogen level enhanced pod yield, straw yield and seed protein content. Mohammed et al. (2014) indicated that most of the parameters measured were remarkably improved by the organic fertilizers application in groundnut cultivation.

\section{Conclusion}

The results reveal that the highest number of pods as well as weights of pods and seeds were achieved in $\mathrm{T} 7$ $\left(\mathrm{N}: \mathrm{P}_{2} \mathrm{O}_{5}: \mathrm{K}_{2} \mathrm{O} @ 22.0: 22.5: 22.5 \mathrm{~kg} / \mathrm{ha}\right.$ with FYM @ 7.5 kg/ha) followed by T5 (FYM@15 ton/hawith N@14 $\mathrm{kg} / \mathrm{ha}$ ). The pod and seed yields were remarkably influenced by the application of fertilizers. Maximum seed yield was recorded in T7 $(2558.02 \mathrm{~kg} / \mathrm{ha})$ followed by T5 $(2521.98 \mathrm{~kg} / \mathrm{ha})$ and T3 $\left(\mathrm{N}: \mathrm{P}_{2} \mathrm{O}_{5}: \mathrm{K}_{2} \mathrm{O} @ 30: 45: 45\right.$ $\mathrm{kg} / \mathrm{ha}(2387.16 \mathrm{~kg} / \mathrm{ha})$. The seed yield in the standard control (T3) was comparatively similar to that (2340.25 kg/ha) in T4 (FYM @ 15 ton/ha alone). The plant treated with FYM alone significantly $(\mathrm{P}<0.05)$ increased the protein and oil contents in seeds over the standard control or combined use of FYM and NPK fertilizers. Based on these results, it could be concluded that highest seed yield with optimal seed protein and oil contents could be obtained by the application of the recommended half doses of NPK fertilizers with farm yard manure @ 7.5 ton/ha as basal dressing and N @ $14 \mathrm{~kg} / \mathrm{ha}$ as top dressing in groundnut cultivation with lesser impact on human health, and environment as compared to the standard control.

\section{Acknowledgement}

This experiment was done through the financial support (Project NARP/12/EUSL/AG 01) under National Agricultural Research Plan (NARP) 2011-2015 from Sri Lanka Council for Agricultural Research Policy (SLCARP), Sri Lanka.

\section{References}

AOAC (1990), Association of Official Analytical Chemists (AOAC), Official Methods of Analysis of the $13^{\text {th }} \mathrm{ed}$. Washington DC, USA.
Adeniyan ON, Ojo AO, Akinbode OA and Adediran JA (2011), Comparative study of different organic manures and NPK fertilizer for improvement of soil chemical properties and dry matter yield of maize in two different soils, J. Soil Sci. Environ. Manage. 2: 9-13.

Alvarez CR, Taboada MA, Boem FHG, Bono A, Fernandez PL and Prystupa P (2009), Topsoil properties as affected by tillage systems in the rolling Pampa region of Argentina, Soil Sci. Soc. Am. J. 73: 1242-1251. DOI: 10.2136/sssaj2008.0246.

Aruyi H, Omid-Beigi R and Kashi A (2000), Effect of nitrogen levels on some characteristics of Cucurbita pepo, J. Pajuhesh Sazandegi 48: 4:9.

Busscher WJ, Novak JM, Evans DE, Watts DW, Niandou M and Ahmedna M (2010), Influence of pecan biochar on physical properties of a Norfolk loamy sand, Soil Sci. 175: 10-14. DOI: 10.1097/SS.0b013e3181cb7f46

Cox TP (2011), Farming in the battlefield: the meanings of war, cattle, and soil in South Kivu, Democratic Republic of the Congo, Disasters 35, article first published online: 13 Oct 2011, DOI: 10.1111/j.1467-7717.2011.01257.x

Esmaeilian Y, Sirousmehr AR, Asghripour MR and Amiri E (2012), Comparison of Sole and Combined Nutrient Application on Yield and Biochemical Composition of Sunflower under Water Stress, Int. J. Appl. Sci. Tech. 2: 214-220.

Hamza MAM and Abd-Elhady ESE (2010), Effect of organic and inorganic fertilization on vegetative growth and volatile oil of marjoram (Majorana hortensis L.) plant, J. Soil Sci. Agric. Eng. 1: 839-851.

Hameed AA, Qayym SM and Usman MUK (1993), Impact of row spacing and NPK fertilizer levels on the growth, seed yield and oil content in peanut, Oil crops Newsletter 10: 50-53.

Ipinmoroti RR, Adeoye GO and Makinde EA (2008), Effect of urea-enriched organic manures on soil fertility, tea seedling growth and pruned yield nutrient uptake in Ibadan, Nigeria, Bulg. J. Agric. Sci. 14: 592-597.

Lado M, Paz A and Ben-Hur M (2004), Organic matter and aggregate size interactions in infiltration, 
seal formation, and soil loss, Soil Sci. Soc. Am. J. 68: $935-942$.

Kandil AA, El-Haleem AKA, Khalafallah MA, El-Habbasha SF, Abu-Hagaza NS and Behairy TG (2007), Effect of nitrogen levels and some bio-fertilizers on dry matter, yield and yield attributes of groundnut, Bull. Natl. Res. Centre (Cairo) 32: 341-359.

Maass BL, Musale DK, Chiuri WL, Gassner A and Peters M (2012), Challenges and opportunities for smallholder livestock production in post-conflict South Kivu, eastern DR Congo, Trop. Anim. Health Prod. 44: 1221-1232. DOI10.1007/s11250-011-0061-5.

Miller JJ, Beasley BW, Drury CF and Zebart BJ (2009), Barley yield and nutrient uptake for soil amended with fresh composted cattle manure, Agron. J. 101: 1047-1060. DOI: 10.2134/agronj2009.0057

Mohammed TA, Elsheikh EAE and Osman AG (2014), Response of groundnut and faba bean to organic chemical and microbial fertilizers in three types of soils in Sudan, Int. J. Sudan Res. 4: 38-54.

Muhammad D and Khattak RA (2009), Growth and nutrient concentration of maize in pressmud treated saline-sodic soils, Soil Environ. 28: 145-155.

Nagaraj MV, Malligawad LH and Biradar DP (2001), Productivity and economics of confectionery groundnut as influenced by plant density and fertilizer management, Karnataka J. Agric. Sci. 14: 932- 937.

Obour AK, Silveira ML, Vendramini JMB, Adjei MB and Sollenberger LE (2010), Evaluating cattle manure application strategies on phosphorous and nitrogen losses from a Florida spodosol, Agron. J. 102: 1511-1521. DOI: 10.2134/agronj2010.0275
Perucci P, Dumontet S, Bufo S, Mazzatura A and Casucci C. (2000), Effects of organic amendent and herbicide treatment on soil microbial biomass, Biol. Fert. Soils 32: 17-23. DOI:10.1007/s003740000.

Shakil A, Noor Z and Khan SN (2012), Evaluation of manuring practices on root rot disease and agronomic characters of Arachis hypogeae L, Afr. J. Biotech. 11(5): 1119-1122. DOI: 10.5897/AJB11.1342.

Seran TH and Suthamathy N (2013), Effect of combined application of cattle manure and EM on the yield and yield components of groundnut (Arachis hypogaea L.), Bangladesh J. Agric. Res. 38: 1-9. DOI: 10.3329/bjar.v38i1.15184.

Sui Y, Liu X, Jin J, Zhang S, Zhang X, Herbert S and Ding JG (2009), Differentiating the early impacts of topsoil removal and soil amendments on crop performance productivity of corn and soybean in eroded farmland of Chinese Mollisols, Field Crops Res. 111: 276-283. DOI: 10.1016/j.fcr.2009.01.005.

Tirol-Padre A, Ladha JK, Regmi AP, Bhandari AL and Inubushi K (2007), Organic Amendment Affect Soil Parameters in Two Long-Term Rice-Wheat Experiments, Soil Sci. Soc. Am. J. 71: 442-452. DOI: 10.2136/sssaj2006.0141

Veeramani P and Subrahmaniyan K (2011), Nutrient management for sustainable groundnut productivity in India- A Review, Int. J. Eng. Sci. Tech. 3: 8138-8153.

Uzoma KC, Inoue M, Andry H, Fujimaki H, Zahoor A and Nishihara E (2011), Effect of cow manure biochar on maize productivity under sandy soil condition, Soil Use and Manage 27: 205-212. DOI: $10.1111 / \mathrm{j} .1475-2743.2011 .00340 . x$ 